\title{
Growth regulator on oat yield indicators
}

\author{
Dionatan K. Krysczun ${ }^{1}$, José A. G. da Silva², Anderson Marolli', \\ Ana P. B. Trautmann ${ }^{3}$, Alessandro D. Lucio ${ }^{1}$ \& Roberto Carbonera ${ }^{2}$
}

${ }^{1}$ Universidade Federal de Santa Maria/Departamento de Experimentação Agrícola. Santa Maria, RS. E-mail: diona1994@hotmail.com; adlucio@ufsm.br ${ }^{2}$ Universidade Regional do Noroeste do Estado do Rio Grande do Sul/Departamento de Estudos Agrários. Ijuí, RS. E-mail: jagsfaem@yahoo.com.br; carbonera@unijui.edu.br

${ }^{3}$ Universidade Regional do Noroeste do Estado do Rio Grande do Sul/Departamento de Ciências Exatas e Engenharias. Ijuí, RS. E-mail: marollia@yahoo.com.br (Corresponding author); anabrezolin@hotmail.com

\section{Key words:}

Avena sativa trinexapac-ethyl

lodging nitrogen

\begin{abstract}
A B S T R A C T
Growth regulator in oat can reduce lodging with effects on yield indicators. The objective of the study is to define the optimum dose of growth regulator to reduce lodging in oats under different conditions of nitrogen $(\mathrm{N})$ fertilization (reduced, high and very high) and the effects on yield indicators in the succession systems. In each succession system (soybean/ oats and corn/oats), two experiments were conducted, one to quantify biomass yield and the other to estimate grain yield and lodging. In the four experiments, the design was randomized blocks with four replicates in $3 \times 4$ factorial scheme, for $\mathrm{N}$-fertilizer doses (30, 90 and $\left.150 \mathrm{~kg} \mathrm{ha}^{-1}\right)$ and growth regulator doses $\left(0,200,400\right.$ and $\left.600 \mathrm{~mL} \mathrm{ha}^{-1}\right)$, respectively. Growth regulator reduces lodging in oat plants, with the ideal doses of $500 \mathrm{~mL} \mathrm{ha}^{-1}$ in the soybean/oat system and $400 \mathrm{~mL} \mathrm{ha}{ }^{-1}$ in the corn/oat system, regardless of the reduced, high and very high $\mathrm{N}$ doses. There is a linear reduction of biological and straw yields, and a quadratic trend in the expression of grain yield and harvest index as a function of the growth regulator doses, regardless of succession systems (soybean/oats and corn/oats).
\end{abstract}

\section{Palavras-chave: \\ Avena sativa trinexapac-ethyl acamamento nitrogênio}

\section{Regulador de crescimento sobre os indicadores de produtividade da aveia}

\begin{abstract}
R E S U M O
O regulador de crescimento em aveia pode reduzir o acamamento com reflexos nos indicadores de produtividade. O objetivo do estudo é a definição da dose ótima do regulador de crescimento para redução no acamamento de plantas de aveia, em condições de reduzida, alta e muito alta fertilização com nitrogênio e os reflexos sobre os indicadores de produtividade nos sistemas de sucessão. Em cada sistema de sucessão (soja/aveia e milho/aveia), dois experimentos foram conduzidos, um para quantificar a produtividade de biomassa e, o outro, para estimativa da produtividade de grãos e o acamamento. Nos experimentos, o delineamento foi o de blocos casualizados com quatro repetições em fatorial $3 \times 4$ para doses de $\mathrm{N}$-fertilizante $\left(30,90\right.$ e $\left.150 \mathrm{~kg} \mathrm{ha}^{-1}\right)$, fonte ureia, e doses de regulador de crescimento $\left(0,200,400\right.$ e $\left.600 \mathrm{~mL} \mathrm{ha}^{-1}\right)$ de princípio ativo TrinexapacEthyl, respectivamente. $\mathrm{O}$ regulador de crescimento reduz o acamamento de plantas de aveia, com a dose ideal em $500 \mathrm{~mL} \mathrm{ha}^{-1}$ no sistema soja/aveia e de $400 \mathrm{~mL} \mathrm{ha}^{-1}$ no sistema milho/aveia, independentemente da dose reduzida, alta e muito alta de nitrogênio. Há redução linear da produtividade biológica e de palha, e comportamento quadrático na expressão da produtividade de grãos e índice de colheita em função das doses de regulador, independentemente dos sistemas de sucessão (soja/aveia e milho/aveia).
\end{abstract}




\section{INTRODUCTION}

The expression of oat yield is associated with genetic characteristics of the cultivars, weather conditions during cultivation and use of management technologies (Brezolin et al., 2016; Romitti et al., 2016). In the management, the new oat biotypes are highly responsive to the use of nitrogen $(\mathrm{N})$, which directly impacts yield indicators (Silva et al., 2015; Mantai et al., 2016). On the other hand, higher $\mathrm{N}$ doses, combined with favorable climatic conditions, promote vegetative growth, leading to lodging (Flores et al., 2012).

Lodging is the phenomenon that results in bent plants with possible break of the stem, compromising the translocation of photoassimilates (Gomes et al., 2010), directly affecting grain yield and quality (tg). One practice to control lodging in oat (Schwerz et al., 2015), barley (Amabile et al., 2004) and rice (Arf et al., 2012), is the use of growth regulators. Regulators are chemical compounds that act in the reduction of stem internode length through the inhibition of gibberellin (Espindula et al., 2010).

Oat is one of the agronomic species most affected by lodging, especially more-expressive increments in grain yield are intended using higher $\mathrm{N}$ doses (Arenhardt et al., 2017). In addition, studies on the effects of growth regulator on oat yield indicators in the cultivation systems are scarce, indicating the need to conduct the present study as a support in the use of such technology for this species.

Hence, this study aimed to define the optimum dose of growth regulator to reduce lodging in oat plants, under reduced, high and very high conditions of $\mathrm{N}$ fertilization, and evaluate the effects on yield indicators in the succession systems.

\section{Material AND Methods}

The study was carried out at the field, in the agricultural year 2015, in the municipality of Augusto Pestana, RS. The soil in the experimental area was classified as typic dystroferric Red Latosol (Santos et al., 2006) and the climate of the region, according to Köppen's classification, is Cfa, with hot summer without dry season. Soil analysis was made twenty days before sowing, to determine the following chemical characteristics (Tedesco et al., 1995):

i) Soybean/oat system $\left(\mathrm{pH}=6.2 ; \mathrm{P}=33.9 \mathrm{mg} \mathrm{dm}^{-3} ; \mathrm{K}=\right.$ $200 \mathrm{mg} \mathrm{dm}^{-3} ; \mathrm{OM}=3.0 \% ; \mathrm{Al}=0 \mathrm{cmol}_{\mathrm{c}} \mathrm{dm}^{-3} ; \mathrm{Ca}=6.5 \mathrm{cmol}_{\mathrm{c}}$ $\mathrm{dm}^{-3}$ and $\left.\mathrm{Mg}=2.5 \mathrm{cmol}_{\mathrm{c}} \mathrm{dm}^{-3}\right)$

ii) Corn/oat system $\left(\mathrm{pH}=6.5 ; \mathrm{P}=34.4 \mathrm{mg} \mathrm{dm}^{-3} ; \mathrm{K}=262\right.$ $\mathrm{mg} \mathrm{dm}{ }^{-3} ; \mathrm{OM}=2.9 \% ; \mathrm{Al}=0 \mathrm{cmol}_{\mathrm{c}} \mathrm{dm}^{-3} ; \mathrm{Ca}=6.6 \mathrm{cmol}_{\mathrm{c}} \mathrm{dm}^{-3}$ and $\left.\mathrm{Mg}=3.4 \mathrm{cmol}_{\mathrm{c}} \mathrm{dm}^{-3}\right)$.

Sowing was performed in the third week of June, according to the recommendation of cultivation, on residual cover with high (120/1) and reduced (30/1) C/N ratio, in soybean/oat and corn/oat systems, respectively. At sowing, a seeder-fertilizer machine was used to compose the plots with five 5-m-long rows spaced by $0.20 \mathrm{~m}$, forming the experimental unit of $5 \mathrm{~m}^{2}$. Population density was equal to 400 viable seeds $\mathrm{m}^{-2}$. During the experiment, plants received applications of the fungicide Tebuconazole at dose of $0.75 \mathrm{~L} \mathrm{ha}^{-1}$. Weeds were controlled using the herbicide Metsulfuron-methyl at dose of $4 \mathrm{~g} \mathrm{ha}^{-1}$ and weedings always when necessary. At sowing, 45 and $30 \mathrm{~kg} \mathrm{ha}^{-1}$ of $\mathrm{P}_{2} \mathrm{O}_{5}$ and $\mathrm{K}_{2} \mathrm{O}$, respectively, were applied based on the $\mathrm{P}$ and $\mathrm{K}$ contents in the soil for an expected grain yield of $3 \mathrm{tha}^{-1}$. In addition, $10 \mathrm{~kg} \mathrm{ha}^{-1}$ of $\mathrm{N}$ was applied at planting and the rest, to contemplate the studied doses, was applied in the phenological stage of fourth expanded leaf, in the form of urea. Growth regulator (trinexapac-ethyl) was applied with a backpack sprayer at constant pressure of $30 \mathrm{lb} \mathrm{pol}^{-2}$, by compressed $\mathrm{CO}_{2}$, using flat-jet nozzles, following the technical recommendation for the wheat crop between the phenological stage of $1^{\text {st }}$ and $2^{\text {nd }}$ visible node.

In each succession system (soybean/oat and corn/oat), two experiments were conducted, one to quantify biomass yield and the other to estimate grain yield and lodging. In the four experiments, the design was randomized blocks with four replicates in a $3 \times 4$ factorial scheme, for $\mathrm{N}$-fertilizer doses (30, 90 and $\left.150 \mathrm{~kg} \mathrm{ha}^{-1}\right)$, using urea as $\mathrm{N}$ source, and growth regulator doses $\left(0,200,400\right.$ and $\left.600 \mathrm{~mL} \mathrm{ha}^{-1}\right)$. The growth regulator has trinexapac-ethyl as its active principle, and the cultivar used in the experiment was 'Barbarasul', which has high susceptibility to lodging.

Grain yield (GY, kg ha-1) was obtained by cutting three central rows of each plot, close to the soil, at the harvest stage. Samples were dried in a forced-air oven at $65^{\circ} \mathrm{C}$ until constant weight, to correct moisture.

These data were used to estimate straw yield (SY, kg ha-1) by subtraction (BY - GY) and harvest index GY/BY. Lodging (LD, \%) was visually estimated before harvest and expressed in percentage, considering the angle formed in the vertical position of the stem, in relation to the soil, and the area of lodged plants. Such estimate was made using the methodology described by Moes \& Stobbe (1991), defined by the equation: $\mathrm{LD}(\%)=\mathrm{I} \times \mathrm{A} \times 2$, where $\mathrm{I}$ is the inclination degree, which varies from 0 to 5 ( 0 is absence of inclination and 5 all plants are completely lodged), whereas A represents the area with lodged plants in the plot, which varies from 0 to 10 ( 0 corresponds to absence of lodged plants and 10 to lodged plants in the entire plot, regardless of inclination). Thus, this equation weighs the incidence and severity of plant lodging.

After the assumptions of homogeneity and normality were met in Bartlett's test, analysis of variance was carried out to detect main and interaction effects. Means of yield indicators and lodging were compared by Scott-Knott test. Given the trend of linear behavior $\left(\mathrm{Y}=\mathrm{b}_{0} \pm \mathrm{b}_{1} \mathrm{x}\right)$ in plant lodging with the use of the growth regulator, considering the possibility of a maximum plant lodging of $10 \%$, a value added to the parameter "Y" of the equation, to estimate the ideal dose, obtained by $\mathrm{x}=\left[\left(\mathrm{Y}-\mathrm{b}_{0}\right) /\left( \pm \mathrm{b}_{1}\right)\right]$. Linear or quadratic regression equation was fitted to describe the behavior of oat yield indicators. From this point on the values of grain yield, biomass yield, straw yield and harvest index using the ideal dose of the growth regulator for a maximum $10 \%$ lodging were estimated. This value was defined through the contact with researchers in charge of studies using oat and based on results from the literature indicating that cultivars with up to $10 \%$ lodging are considered as resistant to curvature or fall of plants (Romitti et al., 2016). The computer program Genes was used for these determinations. 


\section{Results AND Discussion}

In 2015, the rainfall along the crop cycle was $817 \mathrm{~mm}$, which is close to the historical average of the last 20 years $(900 \mathrm{~mm})$. When $\mathrm{N}$-fertilizer and growth regulator were applied, the soil had adequate moisture conditions due to the accumulation of rainfalls in the previous days (Figure 1).

In the grain filling stage, there was no water stress by excess or deficit of rainfall, and no occurrence of rains close to harvest, a weather condition that is favorable to oat development. Favorable rainfall conditions, as well as $\mathrm{N}$ fertilization, positively act on grain formation (Arenhardt et al., 2015). However, it favors lodging, making harvest difficult and causing losses of yield (Marolli et al., 2017).

The analysis of variance showed significant alterations of oat yield indicators and lodging due to the $\mathrm{N}$ and growth regulator doses in the succession systems (Table 1).

According to the overall mean, there was strong reduction of lodging in the corn/oat system compared with the soybean/oat system (Table 1), showing benefits of this succession, especially aiming at high yield using $\mathrm{N}$. In addition, the large volume of biomass supplied to the system by corn can potentiate greater control of erosion and maintenance of soil moisture. Regardless of the succession system, there was no interaction between $\mathrm{N}$ doses and growth regulator doses, a condition that is highly desirable, allowing the recommendation of an optimal dose of the regulator, regardless of the fertilizer dose supplied to the oat crop.

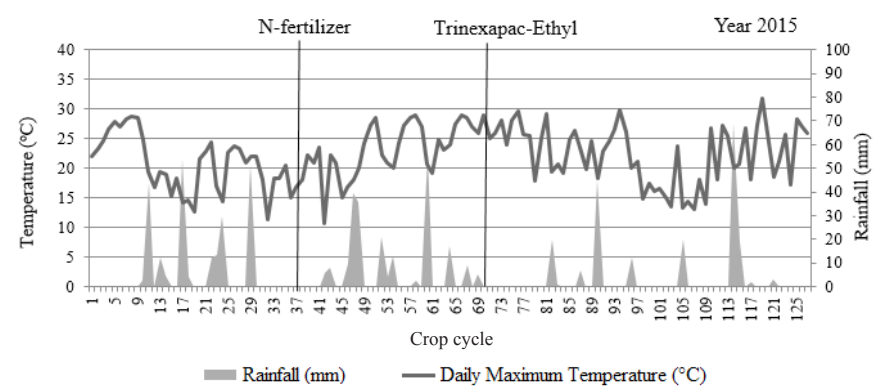

Figure 1. Rainfall and maximum temperature along the oat crop cycle
In the soybean/oat system, regardless of the $\mathrm{N}$-fertilizer dose, the use of $400 \mathrm{~mL} \mathrm{ha}^{-1}$ of the growth regulator promoted higher reduction of lodging, with no losses in grain yield (Table 2). In the analysis of the absolute values, the increment in the doses of growth regulator shows greater tendency of reduction in biological yield and straw yield, regardless of the $\mathrm{N}$-fertilizer dose. Reduction in these variables was expected, because the increment in the growth regulator dose tends to reduce internode length, decreasing straw yield without affecting grain yield.

In the corn/oat system (Table 2), the use of $400 \mathrm{~mL} \mathrm{ha}^{-1}$ of the growth regulator also promoted higher reduction of lodging without affecting grain yield, regardless of $\mathrm{N}$ dose. In this system, according to the analysis of absolute values, there was also a trend of reduction in total biomass due to the reduction of straw yield. As observed in wheat (Schwerz et al., 2015) and rice (Arf et al., 2012), lodging decreased as the growth regulator doses increased, with reduction in the internode length and increment in stem diameter, making the stem more resistant. Oat biomass and grain yield tend to be favored in soybean/oat system by the fast decomposition of the tissues of the leguminous species. In corn/oat system, although the decomposition of tissues in the corn crop is slow, there is a large reduction of oat lodging due to the lower availability of residual N (Silva et al., 2016). Estimating the optimal growth regulator dose with effectiveness in the reduction of lodging and without yield losses is decisive for the employment of this technology. Hence, Table 3 shows the linear equations that describe the expression of lodging as a function of growth regulator doses, followed by the estimate of the optimal dose of the product for a maximum lodging of $10 \%$. The optimal dose was used to predict the expression of oat yield indicators under the conditions of $\mathrm{N}$ use. Still in Table 3, in the soybean/ oat system, the optimal doses of the growth regulator for maximum lodging of $10 \%$ were 490,500 and $508 \mathrm{~mL} \mathrm{ha}^{-1}$, under condition of reduced, high and very high $\mathrm{N}$ fertilization.

High fertilization with $90 \mathrm{~kg} \mathrm{ha}^{-1}$ promoted increment in biological yield, grain yield and straw yield, with reduction in the harvest index. This result was expected because, although

Table 1. Analysis of variance of nitrogen and growth regulator doses on oat yield indicators and lodging in the succession systems

\begin{tabular}{|c|c|c|c|c|c|c|}
\hline \multirow{3}{*}{ Source of variation } & \multirow{3}{*}{ DF } & \multicolumn{5}{|c|}{ Mean Square } \\
\hline & & BY & GY & SY & HI & \multirow{2}{*}{$\begin{array}{l}\text { LD } \\
\text { (\%) }\end{array}$} \\
\hline & & \multicolumn{4}{|c|}{$\left(\mathrm{kg} \mathrm{ha}^{-1}\right)$} & \\
\hline Block & 3 & \multicolumn{5}{|c|}{ Soybean/oat system } \\
\hline Nitrogen dose (N) & 2 & $36745150 *$ & $1275662^{*}$ & $34726431^{*}$ & $0.03042^{\star}$ & $301.56^{\star}$ \\
\hline Growth regulator dose (GR) & 3 & $9703069^{\star}$ & $915162^{\star}$ & $6782673^{*}$ & $0.00512^{*}$ & $10066.66^{\star}$ \\
\hline $\mathrm{N} \times \mathrm{GR}$ & 3 & $874573^{\text {ns }}$ & $54497^{\mathrm{ns}}$ & $610077^{\text {ns }}$ & $0.00022^{\mathrm{ns}}$ & $95.31^{\text {ns }}$ \\
\hline Error & 33 & 189175 & 27229 & 109855 & 0.00009 & 45.83 \\
\hline Total & 47 & & & & & \\
\hline Overall mean & & 10814 & 3354 & 7459 & 0.31 & 60 \\
\hline CV $(\%)$ & & 4.02 & 4.91 & 4.44 & 3.03 & 15 \\
\hline Block & 3 & \multicolumn{5}{|c|}{ Corn/oat system } \\
\hline Nitrogen dose (N) & 2 & $10162250^{*}$ & $1164984^{*}$ & $15194564 *$ & $0.02577^{\star}$ & $114.89^{*}$ \\
\hline Growth regulator dose (GR) & 3 & $9937254^{\star}$ & 231764* & 10838519* & $0.00892^{\star}$ & $3453.29 *$ \\
\hline$N \times G R$ & 6 & $1517728^{\text {ns }}$ & $67582^{\text {ns }}$ & $1688651^{\text {ns }}$ & $0.00129^{\text {ns }}$ & $123.09^{\text {ns }}$ \\
\hline Error & 33 & 510836 & 50864 & 290710 & 0.0001 & 44.46 \\
\hline Total & 47 & & & & & \\
\hline Overall mean & & 11035 & 3248 & 7787 & 0.29 & 20 \\
\hline CV (\%) & & 6.48 & 6.94 & 6.92 & 3.41 & 27.95 \\
\hline
\end{tabular}

* Significant at 0.05 probability level by F test; ns Not significant; BY - Biological yield; GY - Grain yield; SY - Straw yield; HI - Harvest index; LD - Lodging; CV - Coefficient of variation 
Table 2. Means of oat yield indicators and lodging under the conditions of use of nitrogen and growth regulator in the succession systems

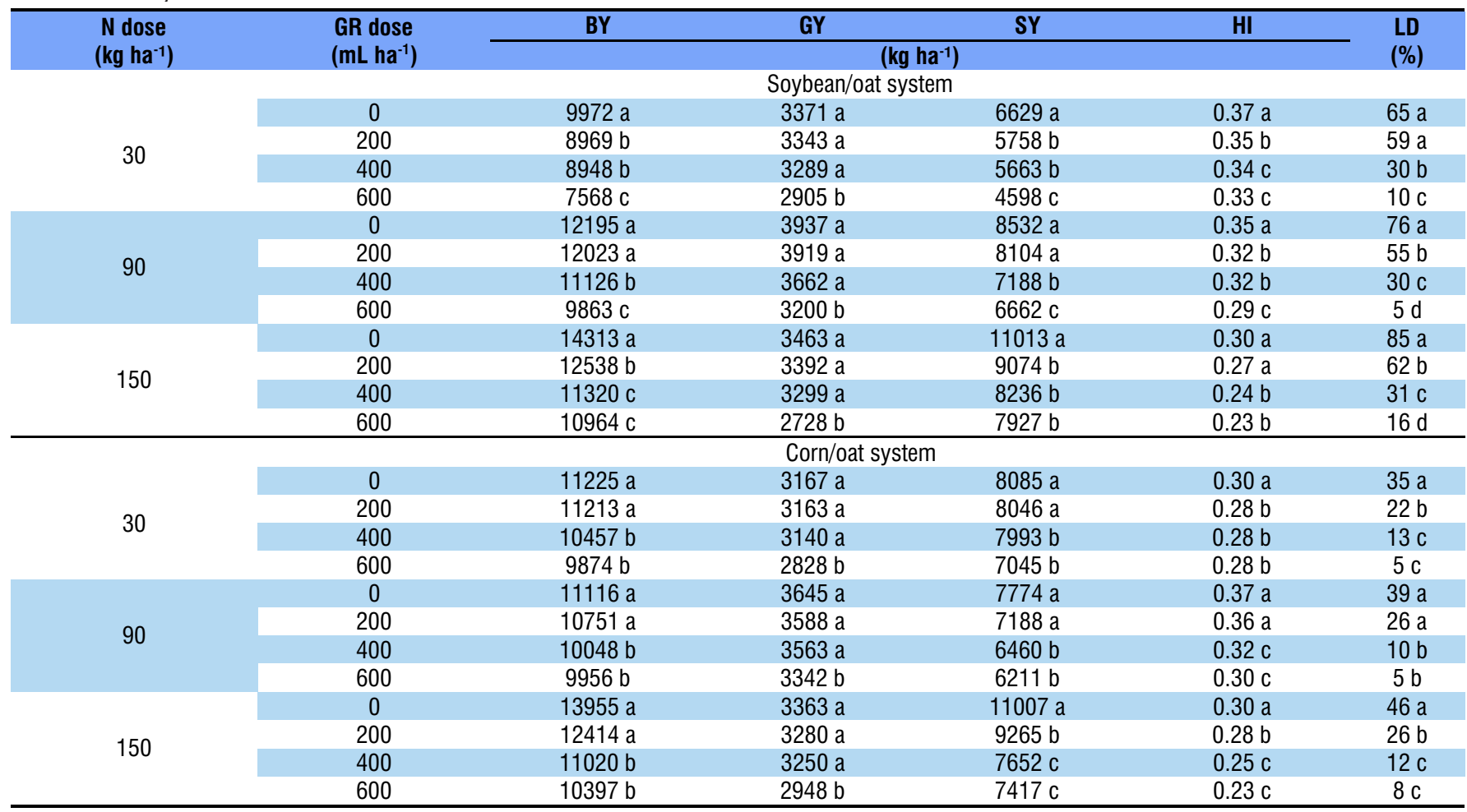

Means followed by the same letters in the column constitute a statistically homogeneous group by Skott-Knott test; N - Nitrogen; GR - Growth regulator; BY - Biological yield; GY - Grain yield; SY - Straw yield; HI - Harvest index; LD - Lodging

Table 3. Regression and estimate of ideal growth regulator dose in oat in the succession systems and $\mathrm{N}$-fertilizer on yield indicators and lodging

\begin{tabular}{|c|c|c|c|c|c|}
\hline $\begin{array}{l}\mathrm{N} \text { dose } \\
\left(\mathrm{kg} \mathrm{ha}^{-1}\right)\end{array}$ & $\begin{array}{c}\text { Equation } \\
Y=a \pm b x \pm c x^{2}\end{array}$ & $\begin{array}{c}\mathrm{R}^{2} \\
(\%)\end{array}$ & $\begin{array}{c}P \\
\left(b_{i} x\right)\end{array}$ & $\begin{array}{l}\text { Ideal dose } \\
\left(\mathrm{mL} \mathrm{ha}^{-1}\right)\end{array}$ & $\mathrm{y}_{\mathrm{E}}$ \\
\hline & \multicolumn{5}{|c|}{ Soybean/oat system } \\
\hline \multirow{5}{*}{30} & $L D=59-0.10 x$ & 95 & * & \multirow{5}{*}{490} & 10 \\
\hline & $\mathrm{BY}=9949-3.61 \mathrm{x}$ & 84 & * & & 8180 \\
\hline & $\mathrm{GY}=3355+0.61 x-0.0022 x^{2}$ & 80 & * & & 3125 \\
\hline & $S Y=6590-3.09 x$ & 98 & * & & 5075 \\
\hline & $\mathrm{HI}=0.33+0.00022 \mathrm{X}-0.34 \cdot 10^{-6} \mathrm{x}^{2}$ & 84 & * & & 0.35 \\
\hline \multirow{5}{*}{90} & $\mathrm{LD}=65-0.11 \mathrm{x}$ & 91 & * & \multirow{5}{*}{500} & 10 \\
\hline & $B Y=12485-3.9 x$ & 99 & * & & 10535 \\
\hline & $\mathrm{GY}=3636+3.04 x-0.0062 x^{2}$ & 96 & * & & 3606 \\
\hline & $S Y=8600-3.26 x$ & 98 & * & & 6970 \\
\hline & $\mathrm{HI}=0.29+0.00026 \mathrm{x}-0.36 .10^{-6} \mathrm{x}^{2}$ & 92 & * & & 0.33 \\
\hline \multirow{5}{*}{150} & $L D=71-0.12 x$ & 98 & * & \multirow{5}{*}{508} & 10 \\
\hline & $B Y=13973-5.63 x$ & 92 & * & & 11112 \\
\hline & $\mathrm{GY}=3281+2.21 \mathrm{x}-0.005 \mathrm{x}^{2}$ & 98 & * & & 3113 \\
\hline & $S Y=10484-4.73 x$ & 91 & * & & 8081 \\
\hline & $H I=0.22+0.00039 x-0.59 \cdot 10^{-6} x^{2}$ & 93 & * & & 0.26 \\
\hline \multirow[t]{2}{*}{ Overall GR dose } & & - & - & $\cong 500$ & - \\
\hline & \multicolumn{4}{|c|}{ Corn/oat system } & \\
\hline \multirow{5}{*}{30} & $L D=29-0.05 x$ & 99 & * & \multirow{5}{*}{380} & 10 \\
\hline & $B Y=11413-2.4 x$ & 80 & ns & & 10501 \\
\hline & $G Y=3125+0.89 x-0.0022 x^{2}$ & 90 & ns & & 3145 \\
\hline & $S Y=8198-1.93 x$ & 89 & ns & & 7465 \\
\hline & $H I=0.27+0.000081 x-0.11 .10^{-6} x^{2}$ & 53 & ns & & 0.28 \\
\hline \multirow{5}{*}{90} & $L D=38-0.07 x$ & 93 & * & \multirow{5}{*}{400} & 10 \\
\hline & $B Y=11068-2.0 x$ & 85 & * & & 10268 \\
\hline & $G Y=3327+1.87 x-0.0023 x^{2}$ & 71 & ns & & 3707 \\
\hline & $S Y=7646-2.45 x$ & 81 & * & & 6666 \\
\hline & $\mathrm{HI}=0.29+0.00028 \mathrm{x}-0.30 .10^{-6} \mathrm{X}^{2}$ & 93 & * & & 0.35 \\
\hline \multirow{5}{*}{150} & $\mathrm{LD}=36-0.06 \mathrm{x}$ & 94 & * & \multirow{5}{*}{433} & 10 \\
\hline & $\mathrm{BY}=13757-6.0 \mathrm{x}$ & 96 & * & & 11159 \\
\hline & $G Y=2916+2.3 x-0.0036 x^{2}$ & 82 & ns & & 3236 \\
\hline & $S Y=10692-6.19 x$ & 92 & * & & 8012 \\
\hline & $H I=0.20+0.00038 x-0.41 .10^{-6} X^{2}$ & 94 & * & & 0.29 \\
\hline Overall GR dose & & - & - & $\cong 400$ & - \\
\hline
\end{tabular}

$P\left(b_{i} x\right)$ - Probability of inclination; *Significant at 0.05 probability level by Scott-Knott test; " ns Not significant; $R^{2}$ - Coefficient of determination; $\mathrm{y}_{\mathrm{E}}$ - Estimated value; $\mathrm{N}$ - Nitrogen; GR - Growth regulator; LD - Lodging; BY - Biological yield; GY - Grain yield; SY - Straw yield; HI - Harvest index 
the increment in $\mathrm{N}$ dose leads to increment in grain yield, greater contribution tends to be obtained in the expression of biological yield via straw, reducing the harvest index. The very high $\mathrm{N}$ dose with $150 \mathrm{~kg} \mathrm{ha}^{-1}$ increased even more the biological yield, reducing grain yield compared with the dose of $90 \mathrm{~kg} \mathrm{ha}^{-1}$, which indicates that this content of the nutrient affects grain formation, causing toxicity. In the different conditions of $\mathrm{N}$ supply, grain yield and harvest index showed a quadratic response, while a decreasing linear response was observed for biological and straw yields in the soybean/oat system, considering the use of the adjusted dose of the growth regulator. In general, in all conditions of $\mathrm{N}$ use, for maximum lodging of $10 \%$, the dose of $500 \mathrm{~mL} \mathrm{ha}^{-1}$ proves to be efficient.

In the corn/oat system (Table 3), the adjusted dose of the growth regulator was obtained with 380,400 and $435 \mathrm{~mL} \mathrm{ha}^{-1}$, under condition of reduced $\left(30 \mathrm{~kg} \mathrm{ha}^{-1}\right)$, high $\left(90 \mathrm{~kg} \mathrm{ha}^{-1}\right)$ and very high $\left(150 \mathrm{~kg} \mathrm{ha}^{-1}\right) \mathrm{N}$ fertilization. The $\mathrm{N}$ doses of 30 and $90 \mathrm{~kg} \mathrm{ha}^{-1}$ led to similar means of biological yield, but grain yield was increased with $90 \mathrm{~kg} \mathrm{ha}^{-1}$ of $\mathrm{N}$, which explains the higher harvest index compared with the reduced dose. The $\mathrm{N}$ dose of $150 \mathrm{~kg} \mathrm{ha}^{-1}$ in the corn/oat system (Table 3 ) increased biological yield with reduction in grain yield, a condition also observed in the soybean/oat system, which indicates toxic effect of the high fertilization.

In the corn/oat system, lower dose of the growth regulator is needed to control oat lodging, which reinforces the contribution of the system with vegetal cover of lower $\mathrm{C} / \mathrm{N}$ ratio, slowly supplying the residual $\mathrm{N}$ contained in the straw. As occurred in the soybean/oat system, the succession with corn also showed quadratic behavior of the expression of grain yield and harvest index, and negative linearity in oat biological and straw yields, regardless of the $\mathrm{N}$ doses with the adjusted dose of the growth regulator. In all conditions of $\mathrm{N}$ use, the growth regulator dose of $400 \mathrm{~mL} \mathrm{ha}^{-1}$ was efficient for maximum lodging of $10 \%$ in oat plants.

In wheat, Penckowski et al. (2010) and Schwerz et al. (2015) obtained adjusted doses between 400 and $500 \mathrm{~mL} \mathrm{ha}^{-1}$, reducing height, total biomass and lodging, without losses in grain yield. In rice, growth regulator doses between 300 and $600 \mathrm{~mL} \mathrm{ha}^{-1}$ reduced lodging without affecting yield (Ünan et al., 2013). Growth regulator dose of $500 \mathrm{~mL} \mathrm{ha}^{-1}$ was efficient in the reduction of lodging in the barley crop, with no effects on grain yield (Amabile et al., 2004). In soybean, efficient reduction of lodging was obtained with the application of $500 \mathrm{~mL} \mathrm{ha}^{-1}$ of the growth regulator (Souza et al., 2013).

\section{Conclusions}

1. Growth regulator reduces oat lodging, with ideal doses of $500 \mathrm{~mL} \mathrm{ha}^{-1}$ in the soybean/oat system and $400 \mathrm{~mL} \mathrm{ha}^{-1}$ in the corn/oat system, regardless of the reduced, high and very high dose of nitrogen.

2. There is a linear reduction of biological and straw yields and quadratic behavior in the expression of grain yield and harvest index, as a function of the growth regulation doses, regardless of the succession system (soybean/oat and corn/oat).

\section{ACKNOWLEDgements}

To the Coordination for the Improvement of Higher Education Personnel (CAPES), National Council for Scientific and Technological Development (CNPq), Rio Grande do Sul Research Support Foundation (FAPERGS) and the Regional University of the Northwest of Rio Grande do Sul (UNIJUÍ), for the financial support to the research and scholarships of Scientific Initiation, Technological Initiation and Research Productivity.

\section{Literature Cited}

Amabile, R. F.; Minella, E.; Valente, C. M. W.; Serra, D. D. da. Efeito do regulador de crescimento Trinexapac-Etil em cevada cervejeira irrigada em áreas de Cerrado do Distrito Federal. Planaltina: Embrapa Cerrados. 2004. 14p. Boletim de Pesquisa e Desenvolvimento

Arenhardt, E. G.; Silva, J. A. G. da; Arenhardt, L. G.; Carbonari, H. P.; Oliveira, A. de C. The nitrogen in grain yield and at lodging oat cultivars. International Journal of Current Research, v.9, p.44701-44708, 2017.

Arenhardt, E. G.; Silva, J. A. G. da; Gewehr, E.; Oliveira, A. C. de; Binelo, M. O.; Valdiero, A. C.; Gzergorczick, M. E.; Lima, A. R. C. de. The nitrogen supply in wheat cultivation dependent on weather conditions and succession system in southern Brazil. African Journal of Agricultural Research, v.10, p.4322-4330, 2015. https:// doi.org/10.5897/AJAR2015.10038

Arf, O.; Nascimento, V. do; Rodrigues, R. A. F.; Alvarez, R. de C. F; Gitti, D. de C.; Sá, M. E. de. Uso de etil-trinexapac em cultivares de arroz de terras altas. Pesquisa Agropecuária Tropical, v.42, p.150158, 2012. https://doi.org/10.1590/S1983-40632012000200008

Brezolin, A. P.; Silva, J. A. G. da; Frantz, F. C. R.; Binelo, M. O.; Valdiero, A. C.; Zimmer, C. M.; Mantai, R. D.; Marolli, A.; Scremin, O. B.; Mazurkievicz, G. The efficiency of wheat yields by nitrogen dose and fractionation. African Journal of Agricultural Research, v.11, p.3440-3449, 2016. https://doi.org/10.5897/AJAR2016.11249

Espindula, M. C.; Rocha, V. S.; Souza, L. T. de; Souza, M. A. de; Grossi, J. A. S. Efeitos de reguladores de crescimento na elongação do colmo de trigo. Acta Scientiarum. Agronomy, v.32, p.109-116, 2010. https://doi.org/10.4025/actasciagron.v32i1.943

Flores, R. A.; Urquiaga, S. S.; Alves, B. J. R.; Collier, L. S.; Morais, R. F. de; Prado, R. de M. Adubação nitrogenada e idade de corte na produção de matéria seca do capim-elefante no Cerrado. Revista Brasileira de Engenharia Agrícola e Ambiental, v.16, p.1282-1288, 2012. https://doi.org/10.1590/S1415-43662012001200004

Gomes, L. S.; Brandão, A. M.; Brito, C. D. de; Moraes, D. F. de; Lopes, M. T. G. Resistência ao acamamento de plantas e ao quebramento do colmo em milho tropical. Pesquisa Agropecuária Brasileira, v.45, p.140-145, 2010. https://doi.org/10.1590/S0100-204X2010000200004

Mantai, R. D.; Silva, J. A. G. da; Arenhardt, E. G.; Sausen, A. T. Z. R.; Binello, M. O.; Bianchi, V.; Silva, D. R. da; Bandeira, L. M. The dynamics of relation oat panicle with grain yield by nitrogen. American Journal of Plant Sciences, v.7, p.17-27, 2016. https://doi.org/10.4236/ajps.2016.71003

Marolli, A.; Silva, J. A. G. da; Romitti, M. V.; Mantai, R. D.; Hawerroth, M. C.; Scremin, O. B. Biomass and grain yield of oats by growth regulator. Revista Brasileira de Engenharia Agrícola e Ambiental, v.23, p.163-168, 2017. https://doi.org/10.1590/18071929/agriambi.v21n3p163-168 
Moes, J.; Stobbe, E. H. Barley treated with ethephon: I. Yield components and net grain yield. Agronomy Journal, v.83, p.86-90, 1991. https://doi.org/10.2134/agronj1991.00021962008300010021x

Penckowski, L. H.; Zagonel, J.; Fernandes, E. C. Qualidade industrial do trigo em função do trinexapac-ethyl e doses de nitrogênio. Ciência e Agrotecnologia, v.34, p.1492-1499, 2010. https://doi. org/10.1590/S1413-70542010000600020

Romitti, M. V.; Silva, J. A. G. da; Marolli, A.; Arenhardt, E. G.; Mamann, Â. T. W. de; Scremin, O. B.; Lucchese, O. A.; Krüger, C. A. M. B.; Arenhardt, L. G.; Bandeira, L. M. The management of sowing density on yield and lodging in the main oat biotype grown in Brazil. African Journal of Agricultural Research, v.11, p.1935-1944, 2016. https://doi.org/10.5897/AJAR2016.10909

Santos, H. G. dos; Jacomine, P. K. T.; Anjos, L. H. C. dos; Oliveira, V. A. de; Oliveira, J. B. de; Coelho, M. R.; Lumbreras, J. F.; Cunha, T. J. F. Sistema brasileiro de classificação de solos. 2.ed. Rio de Janeiro: Embrapa Solos, 2006. 306p.

Schwerz, F.; Caron, B. O.; Schmidt, D.; Oliveira, D. M. de; Elli, E. F.; Eloy, E.; Rockenbach, A. P. Growth retardant and nitrogen levels in wheat agronomic characteristics. Científica, v.43, p.93-100, 2015. https://doi.org/10.15361/1984-5529.2015v43n2p93-100
Silva, J. A. G. da; Goi Neto, C. J.; Fernandes, S. B. L.; Mantai, R. D.; Scremin, O. B.; Pretto, R. Nitrogen efficiency in oats on grain yield with stability. Revista Brasileira de Engenharia Agrícola e Ambiental, v.20, p.1095-1100, 2016. https://doi. org/10.1590/1807-1929/agriambi.v20n12p1095-1100

Silva, J. A. G. da; Mantai, R. D.; Oliveira, A. C. de; Fontaniva, C.; Arenhardt, E. G.; Olegário, M. B.; Sberse, V. de L. Sowing density on oat production physiological parameters. Científica, v.43, p.181-189, 2015. https://doi.org/10.15361/1984$5529.2015 \mathrm{v} 43 \mathrm{n} 3 \mathrm{p} 226-235$

Souza, C. A.; Figueiredo, B. P.; Coelho, C. M. M.; Casa, R. T.; Sangoi, L. Plant architecture and productivity of soybean affected by plant growth retardants. Bioscience Journal, v.29, p.634-643, 2013.

Tedesco, M. J.; Gianello, C.; Bissani, C. A.; Bohnen, H.; Volkweiss, S. J. Análise de solo, plantas e outros materiais. 2.ed. Porto Alegre: UFRGS, 1995.

Ünan, R.; Sezer, I.; Şahin, M.; Mur, L. A. J. Control of lodging and reduction in plant length in rice (Oryza sativa L.) with the treatment of trinexapac-ethyl and sowing density. Turkish Journal of Agriculture and Forestry, v.37, p.257-264, 2013. https://doi. org/10.3906/tar-1207-72 